DOI: https://doi.org/10.31933/dijemss.v2i2 Received: 25 August 2020, Revised: 15 October 2020, Publish: 24 December 2020

\begin{tabular}{|c|c|c|}
\hline PINASTISTER & $\begin{array}{l}\text { DIJEMSS } \\
\text { DINASTI INTERNATIONAL JOURNAL } \\
\text { OF EDUCATION MANAGEMENT AND } \\
\text { SOCIAL SCIENCE }\end{array}$ & $\begin{array}{r}\text { https://dinastipub.org/DIJEMSS } \\
\text { editor@dinastipub.org } \\
08117401455 \Omega\end{array}$ \\
\hline
\end{tabular}

\title{
THE EFFECT OF ORGANIZATIONAL COMMITMENT AND COMPENSATION ON TURNOVER INTENTION WITH JOB SATISFACTION AS AN INTERVENING VARIABLE FOR EMPLOYEES OF PT INTERCOM PADANG
}

\author{
Yunita $^{1}$ \\ 1) Universitas Putra Indonesia YPTK Padang, Indonesia, itayunita1967@gmail.com
}

Corresponding Author: Yunita

\begin{abstract}
This study aims to determine how much influence organizational commitment and organizational commitment and compensation as the independent variable $(X)$ and job satisfaction as an intervening variable $(Z)$. The analytical method used in this research is the path analysis model. Based on it can be concluded that organizational commitment has a negative and significant effect on employee turnover intention at PT Intercom Padang 10.000 $<0.05)$. Based on the results of testing the second hypothesis, it was found that compensation had a negative effect on turnover intention (0.000 <0.05). Based on the results of testing the third hypothesis that organizational commitment has a negative and significant effect on employee job satisfaction at PT Intercom Padang. (0.000 <0.05). In the fourth hypothesis testing stage, it was found that compensation had a negative effect on job satisfaction. employees at PT Intercom Padang Branch. $(0.001<0.05)$. while the results of testing the fifth hypothesis found that job satisfaction has a negative effect on turnover intention). With the fulfillment of these requirements, it can be proven that organizational commitment and compensation have an effect on turnover intention after going through job satisfaction as an intervening variable for employees of PT Intercom Padang.
\end{abstract}

Keywords: Organizational Commitment, Compensation, Job Satisfaction and Turnover Intention.

\section{INTRODUCTION}

In the last few years, competition in the automotive world has continued to increase, the increasing number of vehicle brands entering the Indonesian market has made people more selective in choosing various brands of vehicles they want. In the context of compensation have on turnover intention with job satisfaction as an intervening variable for employees of PT Intercom Padang. In this study, turnover intention is used as the dependent variable (Y), creates competitive advantage and increases sales volume, each automotive manufacturer has distributors spread across all districts and cities in Indonesia. One of the world's automotive manufacturers that already has a name in Indonesia is Toyota. The Japanese automotive manufacturer has marketed a wide variety of products to the Indonesian market and is reaping success because the Indonesian people are very interested in it, PT Intercom 
The amount of work pressure due to high targets also resulted in an increase in employee turnover rates during 2019. Not achieving the targets imposed prompted the company to be forced to release a number of salespeople as a form of punishment. Based on data obtained from the personnel department of PT Intercom, Padang Branch, it is known that the development of employee turnover is shown in Figure 1. below:

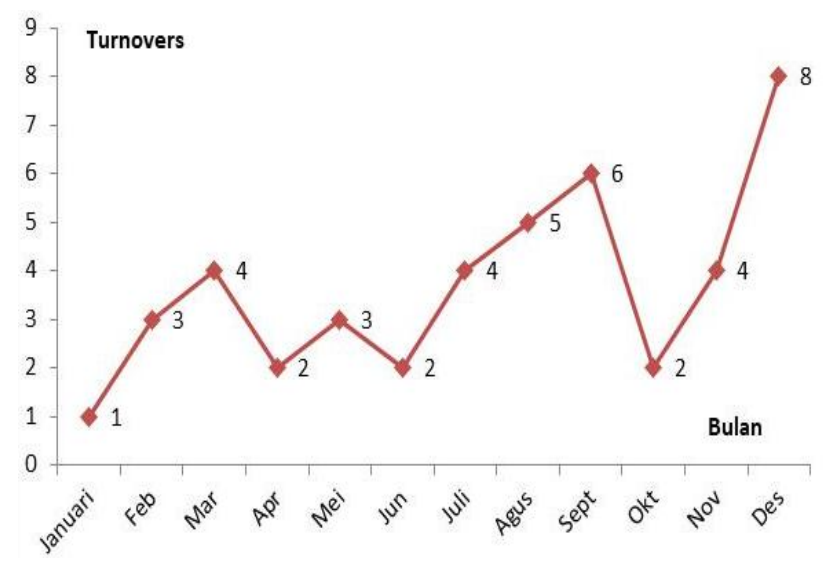

Figure 1

Employee Turnover Development PT Intercom Padang

In Figure 1, it can be seen that the increase in employee turnover, especially the sales department, is relatively high. It can be seen from the data every month that there are at least 2 employees who choose to resign. The graph shows that the highest turnover rate occurred in December 2019. The high turnover rate certainly affects the psychological side of other employees, besides the high turnover will create losses for the company, because recruiting new employees certainly requires a large amount of money. Therefore, efforts to reduce the turnover rate must be carried out by the management of PT Intercom, Padang Branch.

The high turnover rate starts from the desire to leave the company. This desire is known as turnover intention. According to (Robbins and Judge, 2016) turnover intention is a desire or desire that is stored in employees to leave the company they are currently working for. When an employee has a high turnover intention in him, it will affect the employee's contribution to the company, even the tendency for turnover intention will decrease employee performance, so it is very important for the leadership to try to reduce the turnover intention in the employee. According to (Setiawan and Harahap, 2016) the turnover intention that exists in each employee is formed because of a number of variables that can influence it. These variables include organizational commitment and compensation. In addition, according to (Sentana et al., 2017), it is stated that turnover intention can also be influenced by job satisfaction felt by employees. Each of the variables mentioned can encourage the increase and decrease of turnover intention in each employee

According to (Robbins and Judge, 2016) turnover intention is a natural thing that occurs in every employee, but it is very important for companies to try to reduce turnover intentions that arise. One of the steps that can be used by company management is to increase employee job satisfaction. (Mowday and Sutton, 2017) reveal that job satisfaction is a match between the desires or expectations that employees expect with the reality they receive. The higher the job satisfaction will create a stronger commitment in employees at work and can reduce their desire to leave the company. 
A number of previous research results discussing the effect of job satisfaction on turnover intention have been carried out by (Susilo and Satrya, 2019) who found that job satisfaction has a negative effect on employee turnover intention. Furthermore, the results of research (Pawesti and Wikansari, 2017) found that high job satisfaction will reduce turnover intention in employees. Different research results were obtained by (Waspodo et al., 2013) who found that job satisfaction did not have a significant effect on employee turnover intention.

Mowday and Sutton, (2017) that organizational commitment has a negative effect on employee turnover intention. Organizational commitment shows the promise or pledge that employees have at the company where they work. The stronger the commitment of an employee, which is seen in an affective, normative, and continuous commitment, the lower the turnover intention in each employee. A number of previous research results have stated that organizational commitment has a negative effect on employee turnover intention, some of these studies were conducted by Natassia, (2017) which revealed that the stronger organizational commitment that is in an employee will lead to weakening turnover intention in employees. Similar results are also explained in research conducted by (Lauren, 2017) and research conducted by (Pratama, 2018) who both found that strong organizational commitment in each employee will make them more comfortable in the company so that turnover intention to decline.

Besides organizational commitment, according to Rivai and Sagala, (2016) the increase in turnover intention can be influenced by the compensation they receive. Compensation shows remuneration or appreciation given by the company to employees. When employees feel that the compensation they receive is below the wishes or expectations they expect, their turnover intention will strengthen. This statement is also reinforced by a number of research results conducted by a number of previous researchers, including (Sandy, 2019) who found compensation has a negative effect on employee turnover intention. Furthermore, the results of research conducted by (Royan Zakaria, 2017) found that the results of research were relatively different from previous researchers, namely that compensation had no significant effect on employee turnover intention.

\section{Hypothesis Development}

\section{The Effect of Organizational Commitment on Turnover Intention}

Mowday and Sutton, (2017) that organizational commitment has a negative effect on employee turnover intention. The results of Natassia's research (2017) which reveal that the stronger organizational commitment that is in an employee will encourage the weakening of turnover intention in employees. Similar results are also explained in research conducted by (Lauren, 2017) and research conducted by (Pratama, 2018). ) who both find that strong organizational commitment in each employee will make them more comfortable in the company so that turnover intention is decreased. Based on the theoretical description and a number of previous research results, the researcher proposes a hypothesis that will be proven immediately, namely:

$\mathrm{H}_{1}$ Organizational commitment affects the turnover intention of Toyota Intercom Padang employees.

\section{The Effect of Compensation on Turnover Intention}

According to Rivai and Sagala, (2016) increasing turnover intention can be influenced by the compensation they receive. The results of the study (Sandy, 2019) found that 
compensation has a negative effect on employee turnover intention. The results obtained can be interpreted as more according to the amount of compensation received by the employees expected, the comfort in working will be formed. The existence of high appreciation from the company encourages a strong commitment in employees to encourage organizational progress, thereby reducing their desire to leave the organization (turnover intention). Furthermore, the results of research conducted by (Royan Zakaria, 2017) found that the results of research were relatively different from previous researchers, namely that compensation had no significant effect on employee turnover intention. Based on the theoretical description and a number of previous research results, the researcher proposes a hypothesis that will be proven immediately, namely:

$\mathrm{H}_{2} \quad$ Compensation affects the turnover intention of Toyota Intercom Padang employees.

\section{Effect of Organizational Commitment on Job Satisfaction}

Setiawan and Harahap, (2016) found that organizational commitment has a positive effect on employee job satisfaction. Furthermore, the results of research conducted by (Pratama, 2018) found that organizational commitment has a positive effect on employee job satisfaction. This finding can be eaten that the higher the implementation of commitment values in employees in the organization will encourage a decrease in turnover intention. Other consistent research results were obtained by (Supiyanto, 2015) who found that organizational commitment has a positive effect on employee job satisfaction. In accordance with a number of descriptions of the results of previous research, the researcher proposes a hypothesis that will be proven immediately, namely:

$\mathrm{H}_{3}$ Organizational commitment affects job satisfaction of employees of Toyota Intercom Padang

\section{The Effect of Compensation on Job Satisfaction}

The results of the study (Natassia, 2017) found that compensation has a positive effect on job satisfaction of employees of CV Lakit Padang. Lauren, (2017) found the results of research that are in line with previous researchers, namely compensation has a positive effect on employee job satisfaction. Sandy, (2019) found that compensation has a positive effect on job satisfaction at PT IDX Indonesia. This result indicates that the higher the value of financial and non-financial compensation received by employees will increase their satisfaction at work. In line with a number of previous research results that have been explained above, the researcher proposes a hypothesis that will soon be proven in this study, namely:

$\mathrm{H}_{4}$ Compensation has an effect on job satisfaction of Toyota Intercom Padang employees

\section{Effect of Job Satisfaction on Turnover Intention}

A number of previous research results discussing the effect of job satisfaction on turnover intention have been carried out by Susilo and Satrya, (2019) who found that job satisfaction has a negative effect on employee turnover intention. Furthermore, Riana's research (2014) found that high job satisfaction will reduce employee turnover intention. Different research results were obtained by (Waspodo et al., 2016) who found that job satisfaction did not have a significant effect on employee turnover intention. In accordance 
with the brief description of a number of theories, the researcher proposes a hypothesis that will be proven in this study, namely:

$\mathrm{H}_{5}$ Job satisfaction affects the turnover intention of PT Intercom Padang employees

\section{The Effect of Organizational Commitment and Compensation on Job Satisfaction}

The results of research conducted by (Pratama, 2018) found that organizational commitment has a positive effect on employee job satisfaction. This finding can be eaten that the higher the implementation of commitment values in employees in the organization will encourage a decrease in turnover intention. Sandy, (2019) found that compensation has a positive effect on job satisfaction at PT IDX Indonesia. This result indicates that the higher the value of financial and non-financial compensation received by employees will increase their satisfaction at work. Based on the theoretical description and a number of previous research results, the researcher proposes a hypothesis that will be proven immediately, namely:

$\mathrm{H}_{6}$ Organizational commitment and compensation have an effect on job satisfaction at Toyota Intercom Padang employees.

\section{The Influence of Organizational Commitment and Compensation on Turnover Intention through Job Satisfaction as an Intervening Variable}

Natassia's research results, (2017) which reveal that the stronger organizational commitment that is in an employee will encourage the weakening of turnover intention in employees. Rivai and Sagala, (2016) that increased turnover intention can be influenced by the compensation they receive. Compensation shows remuneration or appreciation given by the company to employees.

$\mathrm{H}_{7} \quad$ Organizational commitment and compensation affect turnover intention through job satisfaction as an intervening variable for Toyota Intercom Padang employees.

Based on the results of the previous research, a conceptual framework model can be made which will be guided in the hypothesis testing stages, namely:

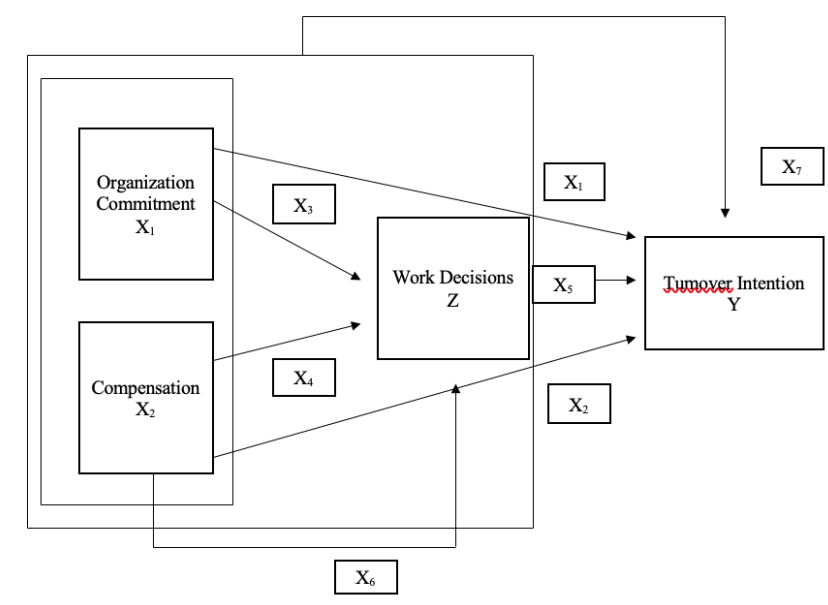

Figure 2.1 Conceptual Framework Model 


\section{RESEARCH METHODS \\ Population and Sample}

Population is a unit of attributes that work together to achieve one specific goal (Sekaran, 2017). In this study, the population is all active employees of the sales section of PT Intercom Padang, amounting to 58 people. Sanpel is part of the population that is considered to be representative, in this study the samples are several employees of PT Intercom Padang. The total number or sample size used is 58 people, or the number of population is the same as the number of samples given the relatively small population size of sales employees.

\section{Operational Definition and Variable Measurement \\ Dependent Variable \\ Turnover Intention}

(Robbins and Judge, 2012) defines turnover intention as a desire or desire that arises in a person to leave the job he is currently doing. In measuring intention turnover, indicators adopted from (Choi et al., 2018) are used, namely the desire to find a new job, find out a better new job, the ability to get a new job and the desire to immediately change jobs.

\section{Independent Variable Organizational Commitment}

According to Mowday and Sutton, (2017) organizational commitment is a promise that all members of the organization have to be loyal, carry out the rules until they are willing to sacrifice for the progress and development of the organization. In measuring organizational commitment, indicators are used from (Allen and Meyer, 1993) in Robbins and Judge, (2016) which consist of three main indicators, namely: Affective commitment, Continuence Commitment and Normative Commitment ( Normative Commitment)

\section{Compensation}

Compensation is the value of rewards or remuneration received by employees in carrying out their duties and responsibilities at work. In measuring compensation, indicators adapted from Arifandi et al (2015) are used, namely direct compensation, indirect compensation and incentives.

\section{Intervening Variables}

It is a variable that mediates the influence of the independent variable on the dependent variable and its nature can strengthen or weaken the influence of the independent variable on the dependent variable.

\section{Job satisfaction}

According to Celluci, Anthony and David De Vries in Rivai and Sagala, (2016) defines job satisfaction as all the conformity between the desires they have before carrying out work with the reality they feel after working. Job satisfaction is measured using indicators adopted from Celluci, Anthony and David De Vries in (Mas'ud, 2017), namely: satisfaction with salaries, satisfaction with promotions, satisfaction with colleagues, satisfaction with supervisors and satisfaction with the work itself. 


\section{RESULTS AND DISCUSSION}

Based on the results of data processing that has been carried out, the demographic description of the respondents is shown in Table 1 below:

Table 1

Demografis Responden

\begin{tabular}{lcc}
\hline \multicolumn{1}{c}{ Demogphic } & Sum & Persentase \\
\hline Gender & 41 & 70.69 \\
Man & 17 & 29.31 \\
Woman & & \\
\hline Age & 30 & 51.72 \\
$23-30$ years old & 15 & 25.86 \\
$31-35$ years old & 11 & 18.97 \\
$36-40$ years old & 2 & 3.45 \\
$41-45$ year old & & \\
\hline Education & 1 & 1.72 \\
SMA & 3 & 5.17 \\
D3 & 51 & 87.93 \\
S1 & 3 & 5.17 \\
S2 & & \\
\hline Years of Carrier & 47 & 81.03 \\
$0-5$ years & 8 & 13.79 \\
6 -10 years & 3 & 5.17 \\
\hline 10 years & 58 & 100 \\
\hline Total & & \\
\hline
\end{tabular}

In Table 4.2, it can be seen that most of the male gender respondents are 41 people or $70.69 \%$ of the total respondents, while the rest are female respondents, namely 17 people or $20.31 \%$ of the total respondents. If it is observed from the age level of the respondents, it is known that most of the respondents have an age between 23 years and 30 years, namely 36 people or $51.72 \%$ of the total respondents, while the respondents with the least number are respondents aged between 41 years to 45 years, namely 2 people or $3.45 \%$ of the total respondents.

In accordance with the data tabulation process, it can be seen that most of the respondents have education at the $S 1$ level, amounting to 51 people or $87.93 \%$ while the rest are respondents who have high school level education, namely only 1 person or $1.72 \%$ of the total respondents. Based on the data tabulation process, it can be seen that most respondents have a working period between zero years and lia years, amounting to 47 people or $81.03 \%$ of the total respondents, while the respondents with the least number are those who have a service period of more than 10 years, amounting to 3 people. or $3.17 \%$ of the total respondents.

\section{Hypothesis test}

\section{The Effect of Organizational Commitment and Compensation on Job Satisfaction}

The t-statistic test aims to prove the effect of the independent variables on the dependent variable individually. Based on the results of the t-statistic test, a summary of the results is shown in Table 2 below: 
Table 2

Sub Structure Testing 2

\begin{tabular}{|c|c|c|c|c|c|c|}
\hline \multirow[b]{2}{*}{ Mod } & & \multicolumn{3}{|c|}{$\begin{array}{l}\text { nstandardizeandardiz } \\
\text { Coefficients oefficien }\end{array}$} & \multirow[b]{2}{*}{$\mathbf{t}$} & \multirow[b]{2}{*}{ Sig. } \\
\hline & & $\mathrm{B}$ & td. Erro & Beta & & \\
\hline \multirow[t]{3}{*}{1} & (Constant) & 5.947 & 3.342 & & 4.193 & .000 \\
\hline & Komiitmen & .825 & .201 & .109 & 4.100 & .000 \\
\hline & Kompensasi & .669 & .176 & .032 & 3.801 & .001 \\
\hline
\end{tabular}

Based on the results of t-statistical testing, it was found that the sig value was 0.000 . The data processing process is carried out using an error rate of 0.05 , the results obtained show that the sig value of 0.000 is far below the 0.05 level of confidence, so the decision is $\mathrm{Ho}$ is rejected and $\mathrm{Ha}$ is accepted so it can be concluded that organizational commitment has a negative and significant effect on employee job satisfaction at PT Intercom Padang. . These findings suggest that the stronger organizational commitment that employees have, the more job satisfaction they feel, especially when working at PT Intercom, Padang Branch.

At the t-statistical test stage, it can be seen that the compensation variable has a sig value of 0.001 . The stages of data processing were carried out using a confidence level of 0.05 . Thus the sig value 0.001 is far below the 0.05 level of confidence. Then the decision is Ho is rejected and Ha is accepted, so it can be concluded that compensation has a negative effect on job satisfaction. Or it can be interpreted that the higher the compensation received by employees will further increase the job satisfaction felt by employees at PT Intercom, Padang Branch.

\section{F-statistical test results}

The F-statistic test aims to prove the effect of the independent variable simultaneously on the dependent variable. Based on the results of data processing that has been carried out, a summary of the results is shown in Table 3 below:

Table 3

F-statistict Testing Result

\begin{tabular}{|c|c|c|c|c|c|c|}
\hline Mod & & $\begin{array}{l}\text { Sum of } \\
\text { Squares }\end{array}$ & $d f$ & ean Squa & $\mathrm{F}$ & Sig. \\
\hline \multirow[t]{3}{*}{1} & Regress & p1.128 & 2 & 150.564 & 9.007 & $.000^{a}$ \\
\hline & Residua & 13.354 & 55 & 16.606 & & \\
\hline & Total & 14.483 & 57 & & & \\
\hline
\end{tabular}

a.Predictors: (Constant), Kompensasi, Komiitmen $O$

b.Dependent Variable: Kepuasan Kerja

Based on the results of the F-statistic test, the sig value is 0.000 . The data processing was carried out using a confidence level of 0.05 . The results obtained show that the sig value of 0.000 is far below the 0.05 level of confidence. So the decision is that Ho is rejected and $\mathrm{Ha}$ is accepted, so it can be concluded that organizational commitment and compensation together have a significant effect on job satisfaction of employees of PT Intercom, Padang Branch.

Sub Structure Framework Model 1 
In accordance with the test results, a structural framework model can be made as shown in Picture 1. below:

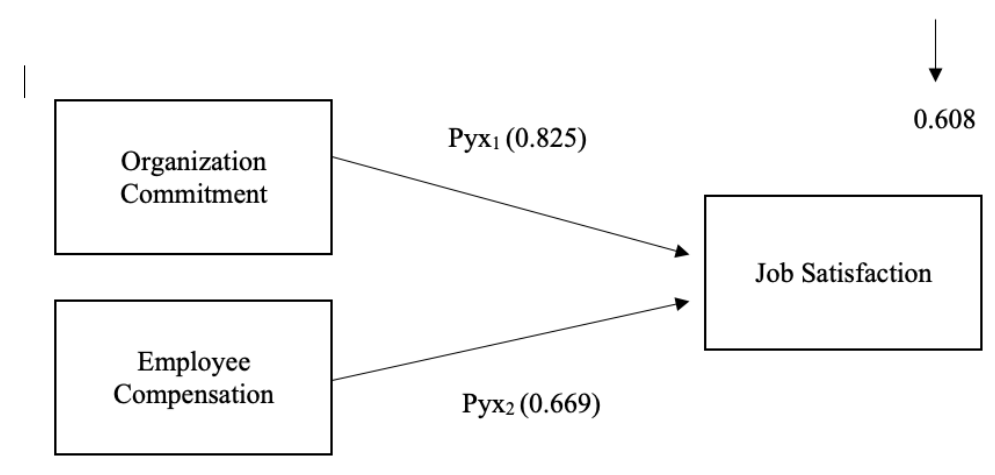

Picture 1

Model Structure 1

\section{Effect of Organizational Commitment, Compensation and Job Satisfaction on Turnover Intention}

In accordance with the results of the t-statistic test, the summary of the results is shown in Table 3 below:

Table 4

Result of t-statistic test for Sub Structure II

\begin{tabular}{|c|c|c|c|c|c|}
\hline \multirow[b]{2}{*}{ Model } & \multicolumn{2}{|c|}{$\begin{array}{l}\text { Unstandardized } \\
\text { Coeffiecienst }\end{array}$} & \multirow{2}{*}{$\begin{array}{c}\begin{array}{c}\text { Unstandardized } \\
\text { Coeffiecieast }\end{array} \\
\text { Beta }\end{array}$} & \multirow[b]{2}{*}{$\mathrm{t}$} & \multirow[b]{2}{*}{ Sig. } \\
\hline & $\mathrm{B}$ & Std. Error & & & \\
\hline $\begin{array}{ll}1 . & \text { (constant) } \\
\text { Organization } \\
\text { Commitment } \\
\text { Compensation } \\
\text { Job Satisfaction }\end{array}$ & $\begin{array}{l}-8.425 \\
-, 638 \\
-, 320 \\
-, 439\end{array}$ & $\begin{array}{r}2.822 \\
.037 \\
0.69 \\
.025\end{array}$ & $\begin{array}{l}-, 813 \\
-, 217 \\
-0,57\end{array}$ & $\begin{array}{r}-2.986 \\
-17.210 \\
-4.613 \\
-3.578\end{array}$ & $\begin{array}{l}.004 \\
.000 \\
.000 \\
.002\end{array}$ \\
\hline
\end{tabular}

Based on the results of t-statistical testing, it was found that the sig value was 0.000 . The data processing was carried out using an error rate of 0.05 , the results obtained showed that the sig value of 0.000 was far below the 0.05 level of confidence, so the decision was Ho was rejected and $\mathrm{Ha}$ was accepted so that it could be concluded that organizational commitment had a negative and significant effect on employee turnover intention at PT Intercom Padang. . These findings suggest that the stronger the organizational commitment of employees, the more likely it is that employee turnover intention at PT Intercom, Padang branch.

At the t-statistical test stage, it can be seen that the compensation variable has a sig value of 0.000 . The stages of data processing were carried out using a confidence level of 0.05 . Thus the sig value of 0.000 is far below the level of confidence 0.05 . Then the decision is that $\mathrm{Ho}$ is rejected and $\mathrm{Ha}$ is accepted, so it can be concluded that compensation has a 
negative effect on turnover intention. Or it can be interpreted that the higher the compensation received by the employee, the lower the employee turnover intention at PT Intercom Padang Branch.

At the third t-statistic test stage, it is seen that the job satisfaction variable has a sig value of 0.002 . The stages of data processing were carried out using a confidence level of 0.05 . Thus the sig value 0.002 is far below the 0.05 level of confidence. Then the decision is that Ho is rejected and $\mathrm{Ha}$ is accepted, so it can be concluded that job satisfaction has a negative effect on turnover intention. Or it can be interpreted that the higher job satisfaction received by employees will further reduce employee turnover intention at PT Intercom, Padang Branch.

F-statistical test results

The F-statistic test aims to prove the effect of the independent variable simultaneously on the dependent variable. Based on the results of data processing that has been carried out, a summary of the results is shown in Table 4 below:

Table 5

F-statistic Result

\begin{tabular}{|c|c|c|c|c|c|c|}
\hline Model & & $\begin{array}{c}\text { Sum of } \\
\text { Squares }\end{array}$ & df & Mean Square & $\mathrm{F}$ & Sig. \\
\hline \multirow[t]{3}{*}{1} & Regression & 5237.581 & 3 & 1745.860 & 237.779 & $.000^{\mathrm{a}}$ \\
\hline & Residual & 396.488 & 54 & 7.342 & & \\
\hline & Total & 5634.069 & 57 & & & \\
\hline
\end{tabular}

Based on the results of the F-statistic test, the sig value is 0.000 . The data processing was carried out using a confidence level of 0.05 . The results obtained show that the sig value of 0.000 is far below the 0.05 level of confidence. Then the decision is that Ho is rejected and $\mathrm{Ha}$ is accepted so that it can be concluded that organizational commitment, compensation and job satisfaction together have a significant effect on the turnover intention of employees of PT Intercom Padang Branch.

\section{Sub Structure Framework Model II}

In accordance with the test results, a structural framework model can be made as shown in Figure 3 below:

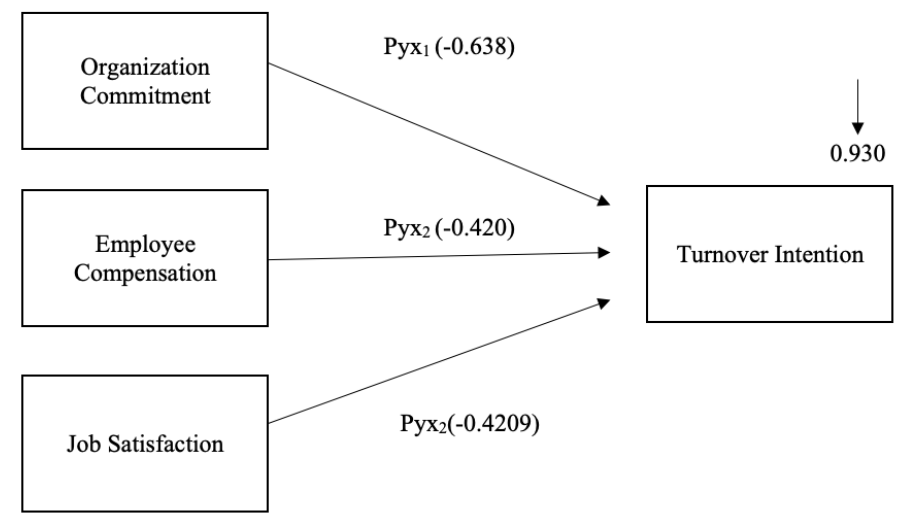

Picture 2

Model Structure 2 
Path Analysis

Finding the Path Coefficient Value

In order to find the path coefficient value, the following calculations are carried out:

$$
\begin{aligned}
& \text { Pyz }=\sqrt{1-R^{2}} \\
& \text { Pyz }=\sqrt{1-0.930} \\
& \text { Pyz }=\sqrt{0.70}=0.836
\end{aligned}
$$

Based on the results of examining the path coefficient value of the regression model formed, it can be concluded that the total contribution of direct and indirect influence between organizational commitment and compensation on turnover intention with job satisfaction as an intervening variable is 0.836 or $83.60 \%$, while the remaining $16.40 \%$ is explained by other variables. which are not used in the current research model.

\section{Seeking Direct Influence}

Direct effect shows the influence between the independent variable on the dependent variable without being controlled by other variables. In general, the calculation of the direct effect in this study is:

a) Direct Impact Commitment Organizational onTurnover intention

$$
\begin{aligned}
\mathrm{PX}_{1} \longrightarrow \mathrm{Py} & =\mathrm{Pyx}_{1} \times \mathrm{Pyx}_{1} \\
& =-0.638 \mathrm{x}-0638 \\
& =0.407
\end{aligned}
$$

b) Direc Impact Compensation on Turnover intention

$$
\begin{aligned}
\mathrm{PX}_{2} \longrightarrow \mathrm{Py} & =\mathrm{Pyx}_{2} \mathrm{x} \mathrm{Pyx}_{2} \\
& =-0.320 \times-0.320 \\
& =0.102
\end{aligned}
$$

c) Direct Impact Job Satisfaction on Turnover intention

$$
\begin{aligned}
\mathrm{PZ} \longrightarrow \mathrm{Py} & =\mathrm{Pyxz}_{1} \times \mathrm{Pyz}_{1} \\
& =-0.429 \times-0.429 \\
& =0.184
\end{aligned}
$$

\section{Indirect Influence}

The indirect effect is to test the effect of the independent variable on the dependent variable occupied by the intermediary or intervening variable. The results of the tests carried out are as follows:

a) Indirect Effect Commitmen Organizational on Turnover intention Trough Job Satisfaction

$$
\begin{aligned}
\mathrm{Px}_{1} \rightarrow \mathrm{Z} \rightarrow \mathrm{Py} & =-0.638 \times 0.948 \times-0.057 \\
& =0.034
\end{aligned}
$$

b) Indirect Effect Organisasional on Turnover intention Through Job Satisfaction

$$
\mathrm{Px}_{2} \rightarrow \mathrm{Z} \rightarrow \mathrm{Py}=-0.320 \times 0.737 \times-0.057
$$




$$
=0.013
$$

Based on the results of testing the direct and indirect effects of each of the research variables used, it appears that the direct effect is greater than the indirect effect. Based on the results of the path analysis test that has been carried out, the researcher summarizes the results of the analysis as shown in Table 5 below:

Table 5

A summary of the Results of the Influence of Direct and indirect

\begin{tabular}{|c|l|c|c|c|}
\hline No & \multicolumn{1}{|c|}{ Testing } & Influence & $\begin{array}{c}\text { Impact } \\
\text { Persentase }\end{array}$ & $\begin{array}{c}\text { Persentase } \\
\text { Acumulation }\end{array}$ \\
\hline 1 & $\mathrm{X}_{1} \rightarrow \mathrm{Y}$ & 0.407 & 40.70 & 40.70 \\
\hline 2 & $\mathrm{X}_{1} \rightarrow \mathrm{Z} \rightarrow \mathrm{Y}$ & 0.034 & 3.40 & 44.10 \\
\hline 3 & $\mathrm{X}_{2} \rightarrow \mathrm{Y}$ & 0.102 & 10.20 & 54.30 \\
\hline 4 & $\mathrm{X}_{2} \rightarrow \mathrm{Z} \rightarrow \mathrm{Y}$ & 0.013 & 1.30 & 55.60 \\
\hline 5 & $\mathrm{Z} \rightarrow \mathrm{Y}$ & 0.184 & 18.40 & 74.00 \\
\hline Impact Tota & & & $74 \%$ \\
\hline \multicolumn{2}{|l|}{ The Rest Of The Contributions } \\
\hline
\end{tabular}

Based on the results of testing the direct and indirect effects, it can be seen that the total effect formed is $74 \%$ while the remaining $26 \%$ contributes to the remaining influence influenced by other variables not used in the current research model. In accordance with the results of the direct and indirect effect testing, a composite structural framework model can be made as shown in Figure 4.4 below:

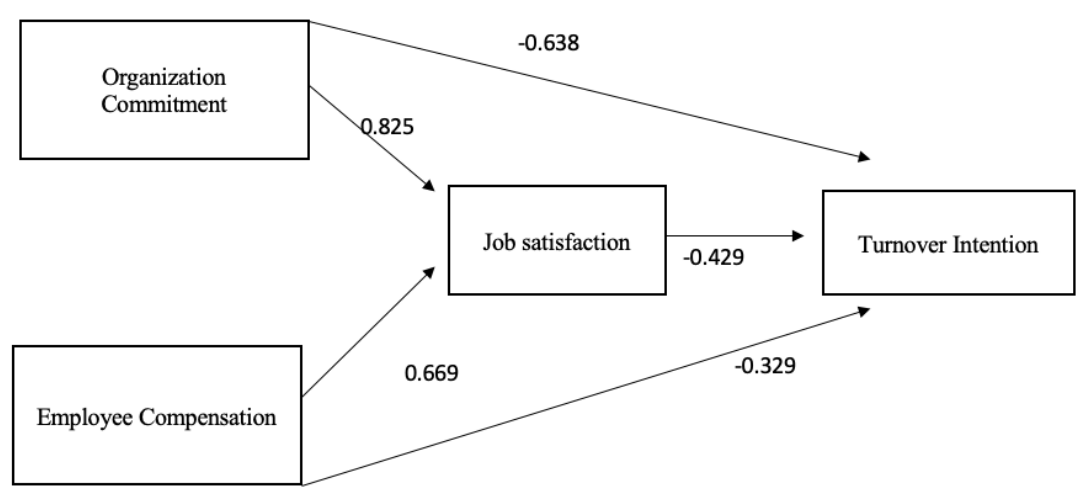




\section{Picture 3 \\ Model Sturucutal}

\section{Discussion}

\section{The Effect of Organizational Commitment on Turnover Intention '}

Based on the results of testing the first hypothesis, it was found that organizational commitment had a negative effect on employee turnover intention at PT Intercon, Padang Branch. The results obtained in the first hypothesis testing stage are in line with the results of research by Natassia, (2017) which revealed that the stronger organizational commitment that is in an employee will encourage weaker turnover intention in employees. Similar results are also explained in research conducted by (Lauren, 2017) and research conducted by (Pratama, 2018) who both found that strong organizational commitment in each employee will make them more comfortable in the company so that turnover intention become decreased in employees.

\section{The Effect of Compensation on Turnover Intention}

Based on the results of testing the second hypothesis it was found that compensation had a negative effect on employee turnover at PT Intercom Padang. These findings indicate that the higher the compensation received by employees, the lower the turnover intention in employees. The results obtained are in line with the results of research by Rivai and Sagala, (2016) that the increase in turnover intention can be influenced by the compensation they receive. Compensation shows remuneration or appreciation given by the company to employees.

\section{The Effect of Organizational Commitment on Job Satisfaction}

Based on the results of testing the first hypothesis it was found that organizational commitment has a positive and significant effect on employee job satisfaction at PT Intercom, Padang Branch. These findings show that the stronger the organizational commitment of employees, the more they feel the job satisfaction they have. The results obtained are in line with the results of research conducted by Setiawan and Harahap, (2016) which found that organizational commitment has a positive effect on employee job satisfaction. Furthermore, the results of research conducted by (Pratama, 2018) found that organizational commitment has a positive effect on employee job satisfaction. Other consistent research results were obtained by (Supiyanto, 2015) who found that organizational commitment has a positive effect on employee job satisfaction.

\section{Effect of Compensation on Job Satisfaction}

Based on the results of testing the fourth hypothesis it was found that compensation had a positive effect on job satisfaction of employees of PT Intercom, Padang Branch. The findings obtained indicate that the higher the compensation received by employees, the more job satisfaction is received. The results obtained are in line with the results of research conducted by (Natassia, 2017) found that compensation has a positive effect on job satisfaction of employees of CV Lakit Padang. Lauren, (2017) found the results of research that are in line with previous researchers, namely compensation has a positive effect on employee job satisfaction. Furthermore, similar research results were obtained by Sandy, (2019) which found that compensation has a positive effect on job satisfaction of PT IDX 
Indonesia. This result indicates that the higher the value of financial and non-financial compensation received by employees will increase their satisfaction at work.

\section{The Effect of Job Satisfaction on Turnover Intention}

Based on the results of testing the third hypothesis it was found that job satisfaction had a negative effect on the turnover intention felt by employees of PT Intercom, Padang Branch. The findings obtained show that the higher the job satisfaction felt by employees will reduce turnover intention in each employee. The findings obtained are in line with the results of research by Susilo and Satrya, (2019) which found that job satisfaction has a negative effect on employee turnover intention. Furthermore, the results of research that are in line are obtained by Riana, (2014) who found that high job satisfaction will reduce turnover intention in employees. The satisfaction that is formed will create feelings of love and strengthen employee commitment to encourage progress in the organization. Besides that, job satisfaction will also create a feeling of comfort at work so as to reduce turnover intention that arises from within employees.

\section{Effect of Organizational Commitment on Turnover Intention with Job Satisfaction as an Intervening Variable}

Based on the results of testing the sixth hypothesis, it was found that organizational commitment has an effect on turnover intention through satisfaction as an intervening variable. The results obtained are in line with the results of Mowday and Sutton's (2017) research, organizational commitment has a negative effect on employee turnover intention. Organizational commitment shows the promises or pledges that employees have at the companies they work for. In addition, strong organizational commitment in employees can also increase job satisfaction felt by employees. Natassia's research results, (2017) reveal that the stronger organizational commitment is in an employee will encourage a weakening of turnover intention, as well as the results of research by Lauren, (2017) and research conducted by Pratama, (2018) which both found that strong organizational commitment in each employee will make them more comfortable in the company. so that turnover intention is decreased.

\section{Effect of Compensation on Turnover Intention with Job Satisfaction as an Intervening Variable}

Based on the results of testing the seventh hypothesis, it was found that compensation has an effect on turnover intention through job satisfaction as an intervening variable. The findings obtained are in line with the results of research conducted by Sandy, (2019) which found that compensation has a negative effect on turnover intention after going through job satisfaction as an intervening variable. The results obtained can be interpreted as more according to the amount of compensation received by the employees expected, then the comfort in working will be formed. The existence of high appreciation from the company encourages a strong commitment in employees to encourage organizational progress, thereby reducing their desire to leave the organization (turnover intention) because in working every employee will certainly feel satisfaction at work. Furthermore, the results of research conducted by (Royan Zakaria, 2017) found that the results of research were relatively different from previous researchers, namely that compensation did not have a significant effect on employee turnover intention after going through job satisfaction as an intervening variable.

\section{CONCLUSION}


In accordance with the analysis and discussion of the results of hypothesis testing that has been carried out, several important conclusions are proposed which are the answers to the problems posed, namely:

1. Based on the results of testing the first hypothesis, the sig value is 0.000 . The data processing was carried out using an error rate of 0.05 . The results obtained showed that the sig value of 0.000 was far below the 0.05 level of confidence, so it could be concluded that organizational commitment had a negative and significant effect on employee turnover intention at PT Intercom Padang. These findings suggest that the stronger the organizational commitment of employees, the more likely it is that employee turnover intention at PT Intercom, Padang branch.

2. Based on the results of testing the second hypothesis the sig value is 0.000 . The stages of data processing were carried out using a confidence level of 0.05 . Thus the sig value of 0.000 is far below the level of confidence 0.05 . So it can be concluded that compensation has a negative effect on turnover intention. Or it can be interpreted that the higher the compensation received by the employee, the lower the employee turnover intention at PT Intercom Padang Branch.

3. Based on the results of testing the third hypothesis, the sig value is 0.000 . The data processing was carried out using an error rate of 0.05 . The results obtained showed that the sig value of 0.000 was far below the 0.05 level of confidence, so it could be concluded that organizational commitment had a negative and significant effect on employee job satisfaction at PT Intercom Padang. These findings suggest that the stronger organizational commitment that employees have, the more job satisfaction they feel, especially when working at PT Intercom, Padang Branch.

4. In the fourth hypothesis testing stage, the sig value is 0.001 . The stages of data processing were carried out using a confidence level of 0.05 . Thus the sig value 0.001 is far below the 0.05 level of confidence. So it can be concluded that compensation has a negative effect on job satisfaction. Or it can be interpreted that the higher the compensation received by employees will further increase the job satisfaction felt by employees at PT Intercom, Padang Branch.

5. In the fifth hypothesis testing stage, the sig value is 0.002 . The stages of data processing were carried out using a confidence level of 0.05 . Thus the sig value 0.002 is far below the 0.05 level of confidence. So it can be concluded that job satisfaction has a negative effect on turnover intention. Or it can be interpreted that the higher job satisfaction received by employees will further reduce employee turnover intention at PT Intercom, Padang Branch.

6. Organizational commitment has an effect on turnover intention after going through job satisfaction as an intervening variable for employees of PT Intercom, Padang Branch. The amount of the indirect effect is 0.034 or $3.40 \%$. These findings show that the stronger organizational commitment that is in line with high job satisfaction will create turnover intention in employees of PT Intercom, Padang Branch, only 3.40\%. Thus, through commitment and job satisfaction felt by employees will be able to reduce turnover intention.

7. Compensation has a negative and significant effect on turnover intention after going through job satisfaction as an intervening variable for employees of PT Intercom, Padang Branch. The amount of the indirect effect is 0.031 or $3.40 \%$. These findings indicate the stronger the appropriate compensation and satisfaction scores

\section{Suggestion}


In accordance with the research conclusions, several suggestions can be put forward that can be used for:

1. For the leadership of the company it is very important for the leadership to inspire and motivate every employee in the PT Intercom Padang environment so that their commitment to the company will be higher so that it can reduce turnover intention in each employee.

2. For company leaders to continue to evaluate and improve the value of compensation that will be received by all employees in the form of salaries, allowances, incentives or allowances, because the greater the value of compensation and the more in accordance with the wishes or expectations of each employee will encourage increased satisfaction. work and reduce turnover intention to employees, especially in the Auto 2000 Padang environment.

\section{REFERENCE}

Agus, I. K., Sentana, D., Bagus, I., \& Surya, K. (2017). Pengaruh Kepuasan Kerja dan Komitmen Organissional Terhadap Turnover Intention, 6(10), 5232-5261.

Allen, N. J., \& Meyer, J. P. (1993). Organizational commitment: Evidence of career stage effects? Journal of Business Research, 26(1), 49-61. https://doi.org/10.1016/0148-2963(93)90042-N

Arikunto, S. (2013). Prosedur Penelitian: Suatu Pendekatan Praktek (Revisi VII). Jakarta: Rineka Cipta.

Choi, S., Cheong, K. J. (KJ), \& Feinberg, R. A. (2018). Moderating effects of supervisor support, monetary rewards, and career paths on the relationship between job burnout and turnover intentions in the context of call centers. Managing Service Quality, 22(5), 492-516

Ghozali, I., \& Latan, H. (2015). Partial Least Squares : Konsep, Teknik dan Aplikasi Menggunakan Program SmartPLS 3.0. Semarang: Badan Penerbit Universitas Diponegoro.

Griffin, R., \& Moorhead, G. (2017). Organizational Behavior: Managing People and Organizations. USA: South-Western Collage Pub.

Hair, J. F., Black, W. C., Babin, B. J., \& Anderson, R. E. (2014). Multivariate Data Analysis: A Global Perspective (7th ed.). New Jersey: Pearson Education.

Judge, S. P. R. \& T. A. (2016). Organizational Behavior (15e ed.). Irwin: McGraw-Hill.

Kreitner, R., Kinicki, A., \& Cole, N. (2018). Fundamentals of organizational behaviour key concepts, skills, and best practices. Canada Cataloguing in Publication, 2, 1-20.

Lauren, J. (2017). Pengaruh Kompensasi Dan Komitmen Organisasional Terhadap Turnover Intention Dengan Kepuasan Kerja Sebagai Variabel Mediasi Pada Karyawan Pt . "X .” Agora, 5(1), 8.

Mas'ud, F. (2017). Survey Diagnosis Organisasional Konsep dan Aplikasi (IV). Semarang: Universitas Diponegoro Press.

Natassia, R. (2017). Pengaruh Komitmen Organisasi Terhadap Kepuasan Kerja Karyawan Pada CV Lakitan Padang. Ekonomi Dan Bisnis, 1(2), 35-44.

Norm Lane, J. \& M. S. (2017). Psikologi Industri/Organisasi Modern. New York: McGraw-Hill.

Pawesti, R., \& Wikansari, R. (2017). Pengaruh Kepuasan Kerja Terhadap Intensi Turnover Karyawan di Indonesia. Jurnal Ecopsy, 3(2). https://doi.org/10.20527/ecopsy.v3i2.2649

Pratama, A. (2018). Pengaruh Komitmen Organisasi dan Kompensasi Terhadap Kepuasan Kerja Serta Dampkanya Terhadap Kinerja Karyawan (Pada Sub Direktorat Bea dan Cukai). Jurnal Semarak, 1(3), 122-141. https://doi.org/10.1017/CBO9781107415324.004

Riana, N. M. D. P. I. G. (2014). Pengaruh Kepuasan Kerja Terhadap Komitmen Organisasional Dan Kualitas Layanan. Jurnal Manajemen, Strategi Bisnis Dan Kewirausahaan, 8(1), 68-80.

Rivai, A. (2019, September 23). Persaingan Bertahan Dalam 45 Perusahaan Elit di Bursa Efek Indonesia. Detik.Com/Financial. Retrieved from www.detik.com/financial

Rivai, V. \& E. J. S. (2016). Manajemen Sumber Daya Manusia Untuk Perusahaan: Dari Teori Ke Praktik (Edisi 3). Jakarta: Rajawali Pers.

Sandy, F. B. (2019). Pengaruh Kompensasi Terhadap Turnover Intention yang Dimediasi Oleh 
Organizational Commitment Karyawan Pt Idx. Jurnal Manajemen, 16(1), 1-19. https://doi.org/10.25170/jm.v16i1.788

Sekaran, U. (2017). Research Methods for Business A Skill Building Approach (14th ed.). New York: John Wiey \& Sons Inc.

Setiawan, D. P., \& Harahap, P. (2016). Danny Putra Setiawan dan Pahlawansyah Harahap Program Pascasarjana Universitas Semarang.

Susilo, J., \& Satrya, I. G. B. H. (2019). Pengaruh Kepuasan Kerja Terhadap Turnover Intention Karyawan Kontrak. E-Jurnal Manajemen Universitas Udayana, 8(6), 3700-3729.

Waspodo, A. A., Handayani, N. C., \& Paramita, W. (2016). Pengaruh Kepuasan Kerja dan Stres Kerja terhadap Turnover Intention pada Karyawan PT. Unitex di Bogor. Jurnal Riset Manajemen Sains Indonesia (JRMSI), 4(1), 97-115.

Winarno, W. W. (2014). Analisis Ekonometrika dan Statistika dengan Menggunakan Eviews (Cetakan 5). Sleman Yogyakarta: UPP STIM YKPN. 